Case Report

\title{
How to Be 80 Year Old and Have a $\mathrm{VO}_{2 \max }$ of a 35 Year Old
}

\author{
Trine Karlsen, 1,2 Ingeborg Megård Leinan,, \\ Fredrik Hjulstad Bækkerud, ${ }^{1}$ Kari Margrethe Lundgren, ${ }^{1}$ Atefe Tari, ${ }^{1}$ \\ Sigurd Loe Steinshamn, ${ }^{1,3}$ Asbjørn Støylen, ${ }^{1,4}$ and Øivind Rognmo ${ }^{1,2}$
}

\author{
${ }^{1}$ K.G. Jebsen Center of Exercise in Medicine, Department of Circulation and Medical Imaging, Norwegian University of Science and \\ Technology, 7491 Trondheim, Norway \\ ${ }^{2}$ St. Olav's University Hospital, Trondheim, Norway \\ ${ }^{3}$ Department of Pulmonary Medicine, St. Olav's University Hospital, Trondheim, Norway \\ ${ }^{4}$ Department of Cardiology, St. Olav's University Hospital, Trondheim, Norway
}

Correspondence should be addressed to Trine Karlsen; trine.karlsen@ntnu.no

Received 6 November 2014; Accepted 2 February 2015

Academic Editor: Masahiro Kohzuki

Copyright (C) 2015 Trine Karlsen et al. This is an open access article distributed under the Creative Commons Attribution License, which permits unrestricted use, distribution, and reproduction in any medium, provided the original work is properly cited.

Background. To discuss the cardiovascular and pulmonary physiology and common risk factors of an 80-year-old man with a world record maximal oxygen uptake of $50 \mathrm{~mL} \cdot \mathrm{kg}^{-1} \cdot \mathrm{min}^{-1}$. Methods. Case report. Results. His maximal oxygen uptake of $3.31 \mathrm{~L} \cdot \mathrm{min}^{-1}$, maximal heart rate of 175 beats $\mathrm{min}^{-1}$, and maximal oxygen pulse of $19 \mathrm{~mL} \cdot$ beats $^{-1}$ are high. He is lean $(66.6 \mathrm{~kg})$ and muscular $(49 \%$ skeletal muscle mass). His echo parameters of mitral flow (left ventricular filling, $E=82 \mathrm{~cm} \cdot \mathrm{s}^{-1}$ and $E / A=1.2$ ) were normal for 40 to 60 -year-old men. Systolic and diastolic function increased adequately during exercise, with no increase in left ventricular filling pressure. He has excellent pulmonary function $\left(\mathrm{FVC}=4.31 \mathrm{~L}, \mathrm{FEV} 1=3.41, \mathrm{FEV} 1 / \mathrm{FVC}=0.79\right.$, and $\left.\mathrm{DLCO}=12.0 \mathrm{Si}^{1}\right)$ and normal

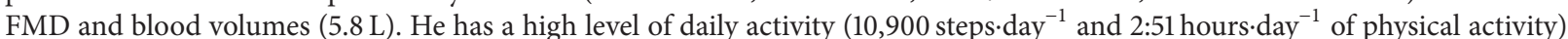
and a lifelong history of physical activity. Conclusion. The man is in excellent cardiopulmonary fitness and is highly physically active. His cardiac and pulmonary functions are above expectations for his age, and his $\mathrm{VO}_{2 \max }$ is comparable to that of an inactive 25-year-old and of a normal, active 35-year-old Norwegian man.

\section{Introduction}

A recent study reported world-record maximal oxygen uptake $\left(\mathrm{VO}_{2 \max }\right)$ for octogenarian endurance athletes of between 34 and $42 \mathrm{~mL} \cdot \mathrm{kg}^{-1} \cdot \mathrm{min}^{-1}$, with reference values for inactive subjects being $21 \mathrm{~mL} \cdot \mathrm{kg}^{-1} \cdot \mathrm{min}^{-1}$ [1]. It is well known that $\mathrm{VO}_{2 \text { max }}$ reduces with aging $[2,3]$, and several factors, including systolic and diastolic heart function, pulmonary function and diffusion capacity, peripheral circulation, and skeletal muscle metabolism and mass, may limit $\mathrm{VO}_{2 \max }[4-$ 6]. Maintaining a high $\mathrm{VO}_{2 \max }$ may be essential for healthy aging, because $\mathrm{VO}_{2 \max }$ is a strong and independent predictor of mortality [7] and protects against cardiovascular mortality and morbidity [8]. Therefore, understanding how to maintain it is vital. The purposes of this publication are to describe the physiology of an 80-year-old man with an extraordinarily high $\mathrm{VO}_{2 \max }$ of $50 \mathrm{~mL} \cdot \mathrm{kg}^{-1} \cdot \mathrm{min}^{-1}$ and to discuss how it is possible to have " $\mathrm{VO}_{2 \max }$ of a 35 -year-old" at 80 years of age. The man's impressively high $\mathrm{VO}_{2 \max }$, combined with a lifelong history of physical activity, is unique and could be a world record at his age.

\section{Methods}

The case was investigated in February and March 2013. First, resting blood pressure and heart rate (Phillips IntelliVue MP50, Germany) and body composition by bioimpedance (InBody 720, Biospace Co., Ltd., Seoul, Korea) were measured, followed by a $\mathrm{VO}_{2 \text { max }}$ treadmill-running test (breathby-breath measurement with the MMX-II, CORTEX Biophysik $\mathrm{GmbH}$, Germany). The test-retest reliability for the equipment used in this study has previously been reported to have a test-retest correlation for oxygen uptake of 0.99 , $p<0.001$, with a coefficient of variation of $1.8 \%$ [9]. After 
a 15-minute warm-up, the $\mathrm{VO}_{2 \text { max }}$ was tested with treadmill running on a fixed inclination of $10 \%$ and an increase in speed approximately every minute until exhaustion. $\mathrm{VO}_{2 \max }$ was defined as the mean of the highest three consecutive 10 -second measurements where the $\mathrm{VO}_{2}$ leveled off despite an increase in speed. The results of the $\mathrm{VO}_{2 \max }$ test were reconfirmed twice in two test laboratories (once in our laboratory and once in a local Olympic training facility laboratory).

Second, after 12 hours of fasting, flow-mediated dilatation (FMD) in the brachial artery was measured with a vascular ultrasound (Vivid 7, GE Vingmed, Norway) [10]; blood samples were collected and analyzed at the St. Olav's hospital's biochemical laboratory, and the total blood, plasma, erythrocyte volume, and hemoglobin mass were measured with the optimized carbon monoxide rebreathing method, where carbon monoxide serves as a marker of hemoglobin (Bayreuth, Germany) [11]. Furthermore, flow-volume spirometry and diffusion capacity were measured with standard procedures (SensorMedics Vmax Encore 22, Homestead, FL, USA), and resting and exercise cycling cardiac echocardiography were performed with an increasing protocol until the heart rate reached $\sim 100$ beats. $\mathrm{min}^{-1}$ (Vivid 7, GE Vingmed, Norway) with simultaneous electrocardiogram ECG recordings (Siemens Medical, Germany). In addition, the man wore a physical activity sensor for 6 days (Armband, Senseware, USA).

The man volunteered to be investigated and have the results published as a case report. The Central Norway Regional Ethical Committee was consulted for ethical advice; however, no application was needed, because the study did not fall under the Norwegian law for medical research. The authors were advised to write an informed consent to the man, explaining in detail the physiological examinations and the publication plan. The authors complied, and the consent form was signed by the man before the physical examinations.

\section{Results}

The man is lean and muscular with a strong upright posture while standing (Figure 1(a)). He has never smoked and is currently medicated with aspirin. No definite indication for aspirin could be found according to established guidelines; the reason for the treatment may be due to the pacemaker, combined with the subjects' age, being taken as an indication of general cardiovascular disease. His blood biomarkers are normal, including normal renal function, and his other demographic variables are displayed in Table 1.

His $\mathrm{VO}_{2 \max }$ is $50 \mathrm{~mL} \cdot \mathrm{kg}^{-1} \cdot \mathrm{min}^{-1}$, corresponding to $3.31 \mathrm{~L} \cdot \mathrm{min}^{-1}$ and $14 \mathrm{METs}$ (14 standard metabolic equivalents) (Figure 1(b)). At maximal effort, his ventilation (VE) was $111 \mathrm{~L} \cdot \mathrm{min}^{-1}$, and his breathing frequency was $41 \mathrm{~L} \cdot \mathrm{min}^{-1}$. His maximal heart rate was 175 beats $\cdot \mathrm{min}^{-1}$, and his oxygen pulse $\left(\mathrm{O}_{2}\right.$-pulse $)$ was $19 \mathrm{~mL} \cdot$ beats $^{-1}$. His anaerobic threshold was at $86 \%$ of $\mathrm{VO}_{2 \max }\left(\mathrm{VO}_{2}=42.8 \mathrm{~mL} \cdot \mathrm{kg}^{-1} \cdot \mathrm{min}^{-1}\right)$. The $\mathrm{VE} / \mathrm{VCO}_{2}$ slope was 29.7. His maximal running speed was $10 \mathrm{~km} \cdot \mathrm{hr}^{-1}$ at $10 \%$ treadmill inclination, and his maximal RER was 1.14 , indicating a high effort during the test.
He received a pacemaker $\sim 10$ years ago and is in a pacemaker rhythm at rest. His lowest resting heart rate was 52 beat $\cdot \mathrm{min}^{-1}$ during sleep and 60 beats $\cdot \mathrm{min}^{-1}$ at daytime. The pacemaker was inserted due to intermittent second-degree AV-block, at the time diagnosed as Mobitz type 2. His cardiac function is described in Table 2, which shows abnormal cardiac motion patterns at rest due to the pacemaker rhythm. During a light-intensity, upright bicycle test, he immediately went into sinus rhythm when he started to pedal, and his heart's motion patterns normalized. Even in pacemaker rhythm, his echo parameters of mitral flow (left ventricular filling) were normal for 40- to 70-year-old men in the HUNT study [12]. There were adequate increases in both systolic and diastolic function during exercise, with no increase in left ventricular filling pressure. Findings were in accordance with a highly trained group of 74-year-old men who were previously studied [4]. His baseline brachial artery diameter was $4.41 \mathrm{~mm}$, and his FMD was $2.72 \%$.

His pulmonary function was above average for his age. His forced ventilator capacity (FVC) was $4.31 \mathrm{~L}$, his forced expiratory volume in one second (FEV1) was $3.41 \mathrm{~L}$, and his FEV1/FVC ratio was 0.79 . His lung diffusion capacity was high, with a DLCO of $12.0 \mathrm{Si}^{1}$. Maximal voluntary ventilation $(\mathrm{MVV})$ was calculated using FEV1 $\times 40$ [13]. Estimated MVV was $136 \mathrm{~L} \cdot \mathrm{min}^{-1}$, and the ratio between $\mathrm{VE}$ at maximal exercise and the calculated MVV was 0.82 . His breathing reserve was $25 \mathrm{~L} \cdot \mathrm{min}^{-1}$.

His total blood, plasma, and erythrocyte volumes were 5.8, 3.6, and 2.2 L, respectively, and his total Hb-mass was $744 \mathrm{~g}$, with hemoglobin and hematocrit values of $14.1 \mathrm{~g} \cdot \mathrm{dL}^{-1}$ and $43 \%$. When expressed per kilogram of body mass, his blood, plasma, and erythrocyte volumes were 87, 54, and $33 \mathrm{~mL} \cdot \mathrm{kg}^{-1}$, respectively, and his total $\mathrm{Hb}$-mass was $11.2 \mathrm{~g} \cdot \mathrm{kg}^{-1}$.

He has a lifelong history of endurance and strengthexercise training. Born and raised on a small farm in a roadless mountain region, his childhood was dominated by the vigorous manual labor of farm work, fishing, hunting, and berry harvesting (Figures $1(\mathrm{c})$ and $1(\mathrm{~d})$ ), as well as exercise training. He has continued this lifestyle as an adult. He currently self-reports $\sim 30$ minutes of structured endurance and strength training 3 times/week (Figure 1(e)), 20 minutes of endurance training, including short durations with moderate-to-lactate threshold intensity, and $\sim 10$ minutes of strength training three times per week, mainly on the upper body and core with 10-12 repetitions per set. Each year, he takes a 7-day ski trip in the mountains and has competed in ultraendurance ski races. His current objectively measured daily activity level is high at 10,843 steps.day ${ }^{-1}$. His total energy expenditure (TEE) was 2,476 Kcal.day ${ }^{-1}$, out of which $877 \mathrm{Kcal}^{- \text {day }^{-1}}$ was due to active energy expenditure (AEE). Daily active time ( $\geq 3 \mathrm{METs}$ ) was $2: 51 \mathrm{hr} \cdot \mathrm{day}^{-1}$, with 2:31 hr.day ${ }^{-1}$ of moderate activity (3-6 METs) and $0: 21 \mathrm{hr} \cdot \mathrm{day}^{-1}$ of vigorous activity (6-9 METs), while no time of $>9$ METs was logged. We are unable to confirm any sports competition results from his early or middle age, but online 


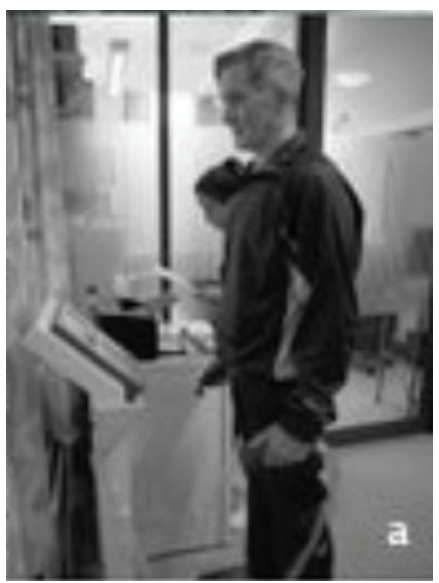

(a)

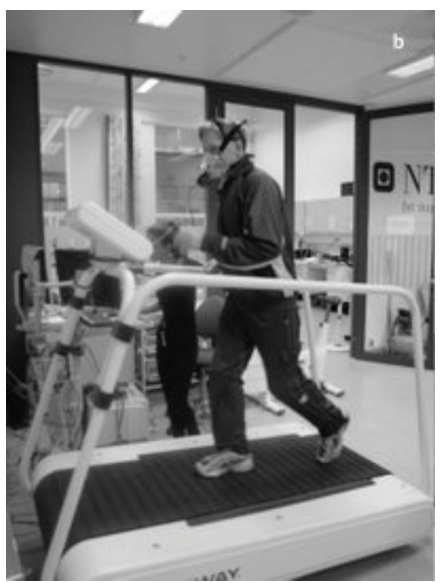

(b)

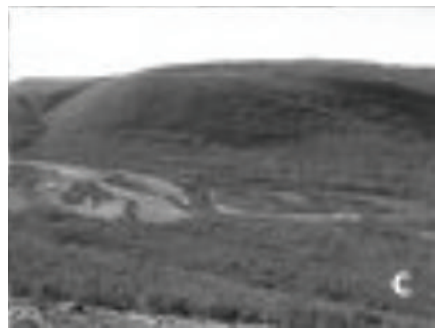

(c)

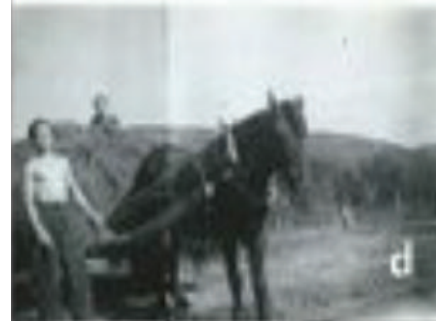

(d)

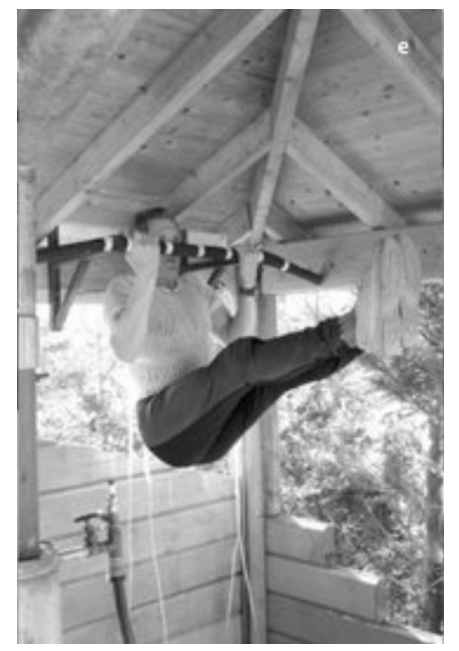

(e)

FIGURE 1: (a) The man measuring body composition. (b) The man running the $\mathrm{VO}_{2 \text { max }}$ test. (c) His childhood farm in Northern Norway. (d) The man doing farm work as a 13-year-old. (e) The man engaged in strength-exercise training in his home gym.

result services from the two major ultraendurance crosscountry ski competitions in Scandinavia, the Birkebeiner $(54 \mathrm{~km})$ and the Vasaloppet $(90 \mathrm{~km})$ ski races, show his participation and completion in three races. In 2007, he completed the Vasaloppet race and, in 2002 and 2004, he completed the Birkebeiner race with finishing times of 4:41:25 and 4:46:04 hours, respectively, coming in as number 130 (65-69-year age group) and number 21 (70-74-year age group) in his respective competition groups. In 2004, he also competed in the Birkebeiner mountain bike race $(89 \mathrm{~km})$ and the Birkebeiner mountain half marathon $(21 \mathrm{~km})$. His finishing times were 4:51:52 and 02:01:45 hours, making him number 5 and number 6 in his age class (70-74-year age group).

\section{Discussion}

The man has a high $\mathrm{VO}_{2 \max }$ for his age, $~ 50 \%$ above the mean for 80-year-old men in Norway [2] and above the 90 percentile $\left(44.2 \mathrm{~mL} \cdot \mathrm{kg}^{-1} \cdot \mathrm{min}^{-1}\right)$ in the ACSM guidelines [14].
His $\mathrm{VO}_{2 \max }$ is higher than the mean of 30- to 39-year-old Norwegian men and inactive 20- to 29-year-old Norwegian men [2], and it is also $8 \mathrm{~mL} \cdot \mathrm{kg}^{-1} \cdot \mathrm{min}^{-1}$ above the highest $\mathrm{VO}_{2 \max }$ reported among 12 Swedish lifelong octogenarian endurance athletes, including a former Olympic champion [1]. His MET value of 14 is high, which places him in the low mortality risk category $\geq 10$ METs $[8,15]$ as well as above the $44.2 \mathrm{~mL} \cdot \mathrm{kg}^{-1} \cdot \mathrm{min}^{-1}$ threshold where an unfavorable cardiovascular risk profile is apparent in Norwegian men [2]. This is supported by his measured risk parameters. The man reports having been tested twice (at 25 and 45 years of age) with cardiopulmonary exercise as part of his work health services, which resulted in a $\mathrm{VO}_{2 \max }$ of $\sim 75$ and $\sim 58 \mathrm{~mL} \cdot \mathrm{kg}^{-1} \cdot \mathrm{min}^{-1}$. This represents a relative $7 \%$ reduction in $\mathrm{VO}_{2 \max }$ per decade, which is comparable to the $6-11 \%$ reduction per decade reported elsewhere in both well-trained and sedentary men $[1,3,16-19]$. His estimated absolute reduction in $\mathrm{VO}_{2 \max }$ of $0.45 \mathrm{~mL} \cdot \mathrm{kg}^{-1} \cdot \mathrm{min}^{-1}$ per year from 25 to 80 years of age is highly comparable to values reported for active subjects in the meta-analysis by Wilson and Tanaka $\left(4.6 \mathrm{~mL} \cdot \mathrm{kg}^{-1} \cdot \mathrm{min}^{-1}\right.$ per 
TABLE 1: Demographic variables.

\begin{tabular}{lc}
\hline Body weight $(\mathrm{kg})$ & 66.6 \\
BMI & 23 \\
Fat mass $(\%)$ & 12 \\
Skeletal muscle mass $(\%)$ & 49 \\
Waist-to-hip ratio & 0.85 \\
Systolic blood pressure $(\mathrm{mmHg})$ & 136 \\
Diastolic blood pressure $(\mathrm{mmHg})$ & 78 \\
Total cholesterol $\left(\mathrm{mmol} \cdot \mathrm{L}^{-1}\right)$ & 4.00 \\
HDL cholesterol $\left(\mathrm{mmol} \cdot \mathrm{L}^{-1}\right)$ & 1.76 \\
LDL cholesterol $\left(\mathrm{mmol} \cdot \mathrm{L}^{-1}\right)$ & 1.99 \\
Triglyceride $\left(\mathrm{mmol} \cdot \mathrm{L}^{-1}\right)$ & 0.55 \\
TSH (mIE $\left.\mathrm{L}^{-1}\right)$ & 1.75 \\
Blood glucose $\left(\mathrm{mmol} \cdot \mathrm{L}^{-1}\right)$ & 5.2 \\
B-HbAlc $(\%)$ & 6.2 \\
C-peptide $\left(\mathrm{nmol} \cdot \mathrm{L}^{-1}\right)$ & 0.3 \\
Creatinin $\left(\mu \mathrm{mol} \cdot \mathrm{L}^{-1}\right)$ & 82 \\
Estimated $\mathrm{GRF}(\mathrm{mL} \cdot \mathrm{min}$ & -1 \\
\hline
\end{tabular}

Demographic description of the case. BMI: body mass index, GRF: glomerular filtration rate, HDL: high density lipoproteins, LDL: low density lipoproteins, TSH: thyroid stimulating hormone.

decade) $[18]$ and in endurance-trained men in the crosssectional study of Pimentel et al. $\left(5.4 \mathrm{~mL} \cdot \mathrm{kg}^{-1} \cdot \mathrm{min}^{-1}\right.$ per decade) [19]. However, he reports that the majority of his decrease in $\mathrm{VO}_{2 \text { max }}$ with increasing age occurred in between 25 and 45 years of age, with $8.5 \mathrm{~mL} \cdot \mathrm{kg}^{-1} \cdot \mathrm{min}^{-1}$ decrease per decade. Between 45 and 80 years of age, his $\mathrm{VO}_{2 \max }$ decreased by only $0.23 \mathrm{~mL} \cdot \mathrm{kg}^{-1} \cdot \mathrm{min}^{-1}$ per year. This is different from what is reported by others, where a minor decrease in $\mathrm{VO}_{2 \max }$ was seen before the age of 50 years and the majority of the $\mathrm{VO}_{2 \max }$ decrease presented beyond this age [19]. The man reports being seriously injured at the age of 42 years, and this could explain the larger degree of decrease in $\mathrm{VO}_{2 \max }$ before the age of 50 years as this injury made him inactive for a period of time. Because the man is highly physically active at the age of 80 and also reports this as being his normal lifestyle, this may explain how he has maintained his absolute $\mathrm{VO}_{2 \max }$ to a greater extent from 50 years of age compared to others, whose reported reduction in $\mathrm{VO}_{2 \max }$ corresponds with a lesser volume of exercise training [19].

His cardiac function (Table 2) is higher than normal for left ventricular volume, with normal function parameters. Despite being in pacemaker rhythm, his diastolic function was normal (tissue Doppler) to super normal (mitral flow), compared to the values from the Norwegian HUNT study [12]. His maximal $\mathrm{O}_{2}$ pulse was high with $19 \mathrm{~mL} \cdot$ beats $^{-1}$, which is, respectively, $9 \%$ and $15 \%$ above men his age in Norway [9] and lifelong Swedish athletes [1], indicating a high maximal stroke volume. He has a high maximal heart rate for his age, 12 beats. $\mathrm{min}^{-1}$ higher than the mean of Norwegian men his age $[9,20]$. Together with a high $\mathrm{O}_{2}$ pulse, this indicates a large cardiac output during exercise. His total blood, plasma, and erythrocyte volumes were $~ 17-$ $19 \%$ higher than those in the published data on older men
TABLE 2: Cardiac findings at rest and light exercise with echocardiography.

\begin{tabular}{|c|c|}
\hline \multicolumn{2}{|l|}{ Rest } \\
\hline Heart rate & 60 \\
\hline Rhythm & Pacemaker \\
\hline End diastolic volume (mL) & 147 \\
\hline Ejection fraction $(\%)$ & 54 \\
\hline Mitral annulus displacement $(\mathrm{cm})$ & 1.2 \\
\hline Mitral flow $E\left(\mathrm{~cm} \cdot \mathrm{s}^{-1}\right)$ & $82^{*}$ \\
\hline Mitral flow $E / A$ & $1.2^{*}$ \\
\hline$E$ Deceleration time (ms) & $199^{*}$ \\
\hline Isovolumic relaxation time (ms) & $94^{*}$ \\
\hline Tissue Doppler systolic velocity $\left(S^{\prime}-\mathrm{cm} \cdot \mathrm{s}^{-1}\right)$ & $8.0^{\S}$ \\
\hline Tissue Doppler early diastolic velocity $\left(e^{\prime}-\mathrm{cm} \cdot \mathrm{s}^{-1}\right)$ & $7.5^{\S}$ \\
\hline$E / e^{\prime}$ & $10.9^{\S}$ \\
\hline \multicolumn{2}{|l|}{ Light exercise } \\
\hline Heart rate & 100 \\
\hline Rhythm & Sinus \\
\hline End diastolic volume (mL) & 124 \\
\hline Ejection fraction $(\%)$ & 80 \\
\hline Mitral flow $E\left(\mathrm{~cm} \cdot \mathrm{s}^{-1}\right)$ & 112 \\
\hline Tissue Doppler early diastolic velocity $\left(e^{\prime}-\mathrm{cm} \cdot \mathrm{s}^{-1}\right)$ & 12.0 \\
\hline$E / e^{\prime}$ & 10.0 \\
\hline
\end{tabular}

Echocardiographic findings at rest and during light, upright bicycle exercise. The $*$ denotes normal values for males in the age interval of 40-60 years in the HUNT study, while $₫$ denotes values that are normal for males in the age range of $>60[12]$.

[21]. Moreover, these volumes were at the levels of normalto-moderate performance endurance athletes [22] and yet below the values of elite athletes [23]. He clearly has an "athlete's" heart with bradycardia; however, no information on this exists from earlier in his life.

His vascular function was normal for his age and gender, with an FMD of $2.7 \%$. His FMD is 3\% below the mean of a Norwegian reference population, but he has a large baseline diameter and no indication of endothelial dysfunction, because his FMD is above 0\% [24]. His blood biomarkers were also normal and low for his age as was his blood pressure, with no indication of elevated cardiovascular risk markers.

His lung function was above average for his age. His FVC, FEV1, and FEV1\% were at $128 \%, 126 \%$, and $97 \%$ of the age-predicted values, respectively. His diffusion capacity was excellent, with a DLCO value at $149 \%$ of the agepredicted value. With a maximal ventilation of $111 \mathrm{~L} \cdot \mathrm{min}^{-1}$, his breathing reserve is normal at $25 \mathrm{~L} \cdot \mathrm{min}^{-1}$ and $82 \%$ of predicted MVV, which is comparable to an age reference value of $26.6 \mathrm{~L} \cdot \mathrm{min}^{-1}$ [16]. Without his supranormal dynamic lung volumes, he probably would have been ventilatorylimited as a "normal for age" FEV1 of approximately $2.70 \mathrm{~L}$, giving a calculated MVV of $108 \mathrm{~L}$, which is below his maximal $\mathrm{VE}$ of $111 \mathrm{~L}$. His $\mathrm{VE} / \mathrm{VCO}_{2}$ slope is normal, despite his high age, indicating a good match of ventilation and perfusion in the pulmonary ventilation, and he has a maximal $\mathrm{VE} / \mathrm{VO}_{2}$ 
of 33.5, indicating a normal ventilatory cost for his oxygen uptake [25].

Despite self-reporting a low volume of systematic exercise training (90 min per week), he is highly physically active, engaging in $83 \%$ more physical activity than the minimum daily recommendation [26]. He walks $\sim 4,100$ steps.day ${ }^{-1}$ more than the mean of Norwegian men above 65 years old and $\sim 2,650$ steps.day ${ }^{-1}$ more than Norwegian men between 20 and 64 years [27]. He outwalks the octogenarian lifelong Swedish athletes by $\sim 2,800$ steps $^{-d_{a y}}{ }^{-1}$ and untrained men by $\sim 6,500$ steps $\cdot$ day $^{-1}$. He is moderately and vigorously active, $1050 \mathrm{~min} \cdot \mathrm{wk}^{-1}$ and $147 \mathrm{~min} \cdot \mathrm{wk}^{-1}$, which is seven times and two times above the recommendations for moderate and high-intensity physical activity of $\geq 150 \mathrm{~min} \cdot \mathrm{wk}^{-1}$ and $\geq 75 \mathrm{~min} \cdot \mathrm{wk}^{-1}$, respectively [26]. His habits may indicate that large volumes of both moderate and vigorous physical activity are needed to maintain a high $\mathrm{VO}_{2 \max }$ at this age, in contradiction to what has been reported by others [18]. The man describes the week he wore the activity sensor as a normal week for him in terms of physical activity. As the sports competition results we have are limited to crosscountry ski races when the man was 69,71 , and 74 years of age, we are unable to discuss the change in performance from young age. There was a slight increase in his competition time from 2002 to 2004 of 4:39 minutes; however, as the weather, snow, and ski conditions are vital for performance in ski races, we are unable to pinpoint the reason for the $\sim 2 \%$ increase in race time. In 2004, he was number 21 in his age group (70-74 years) in the race, while he was number 130 in his age group in 2002 (65-69). Compared to the winning times in his age classes, his race time was a respective $27 \%$ and $10 \%$ slower than the winner in his age group in 2002 (65-69 years) and 2004 (70-74 years), and this is most likely due to him being on the younger end in his competition group in 2004, while he was oldest within his group in 2002.

In addition to endurance exercise training, he reports performing systematic strength training. His maximal or functional muscle strength was not measured in this study; however, his large muscle mass and ability to perform repeatedly high-demand strength exercises (Figure 1(e)) suggest that a strong and functional skeletal muscle mass may positively affect his high cardiopulmonary fitness.

\section{Conclusion}

The 80-year-old man has excellent "35-year-old" cardiopulmonary fitness with a low cardiovascular risk profile and might have a world-record $\mathrm{VO}_{2 \max }$ for his age and gender due to excellent cardiac function (both systolic and diastolic), pulmonary function, and a good match between the cardiac and pulmonary system. In addition, a large, strong skeletal muscle mass; age-elevated blood volume and hemoglobin mass; and normal arterial vascular endothelial function may contribute positively. He is highly physically active and has a lifelong history of physical activity and exercise training. His highly physically active lifestyle may be his "fountain of youth" at 80 years of age, together with a high level of $\mathrm{VO}_{2} \max$ at young age.

\section{Perspectives}

It is possible to be an 80 -year-old man and have a $\mathrm{VO}_{2}$ max of a 35-year-old with a low cardiovascular risk profile. The volume of physical activity for an active and highly fit 80-year-old man is high, seven and two times higher than recommendations for moderate and vigorous physical activity. The reduction in $\mathrm{VO}_{2 \text { max }}$ with aging is normal in the 80 -year-old man, indicating the importance of having a high maximal oxygen uptake at a young age.

\section{Conflict of Interests}

The authors have no conflict of interests to declare.

\section{Acknowledgments}

The authors are grateful for the technical assistance of research nurse Solfrid Meyer Løwensprung during pulmonary function testing, to our case subject, and for pictures courtesy of Julius Margido Jensen. They are also grateful for the picture courtesy of Kåre Grip (Figure 1(c)). Research grants from the Central Norway health authorities, the K.G. Jebsen Center for Exercise in Medicine, and the Norwegian University of Science and Technology covered the salaries of the scientists.

\section{References}

[1] S. Trappe, E. Hayes, A. Galpin et al., "New records in aerobic power among octogenarian lifelong endurance athletes," Journal of Applied Physiology, vol. 114, no. 1, pp. 3-10, 2013.

[2] S. T. Aspenes, T. I. L. Nilsen, E. A. Skaug et al., "Peak oxygen uptake and cardiovascular risk factors in 4631 healthy women and men," Medicine and Science in Sports and Exercise, vol. 43, no. 8, pp. 1465-1473, 2011.

[3] S. W. Trappe, D. L. Costill, M. D. Vukovich, J. Jones, and T. Melham, "Aging among elite distance runners: a 22-yr longitudinal study," Journal of Applied Physiology, vol. 80, no. 1, pp. 285-290, 1996.

[4] H. E. Molmen, U. Wisloff, I. L. Aamot, A. Stoylen, and C. B. Ingul, "Aerobic interval training compensates age related decline in cardiac function," Scandinavian Cardiovascular Journal, vol. 46, no. 3, pp. 163-171, 2012.

[5] R. S. Richardson, C. A. Harms, and R. T. Hepple, "Skeletal muscle: master or slave of the cardiovascular system?" Medicine and Science in Sports and Exercise, vol. 32, no. 1, pp. 89-93, 2000.

[6] D. R. Bassett Jr. and E. T. Howley, "Limiting factors for maximum oxygen uptake and determinants of endurance performance," Medicine and Science in Sports and Exercise, vol. 32, no. 1, pp. 70-84, 2000.

[7] J. Myers, M. Prakash, V. Froelicher, D. Do, S. Partington, and J. E. Atwood, "Exercise capacity and mortality among men referred for exercise testing," The New England Journal of Medicine, vol. 346, no. 11, pp. 793-801, 2002.

[8] S. N. Blair, H. W. Kohl III, R. S. Paffenbarger Jr., D. G. Clark, K. H. Cooper, and L. W. Gibbons, "Physical fitness and all-cause mortality: a prospective study of healthy men and women," Journal of the American Medical Association, vol. 262, no. 17, pp. 2395-2401, 1989. 
[9] H. Loe, Ø. Rognmo, B. Saltin, and U. Wisløff, "Aerobic capacity reference data in 3816 healthy men and women 20-90 years," PLoS ONE, vol. 8, no. 5, Article ID e64319, 2013.

[10] M. C. Corretti, T. J. Anderson, E. J. Benjamin et al., "Guidelines for the ultrasound assessment of endothelial-dependent flowmediated vasodilation of the brachial artery: a report of the international brachial artery reactivity task force," Journal of the American College of Cardiology, vol. 39, no. 2, pp. 257-265, 2002.

[11] W. Schmidt and N. Prommer, "The optimised CO-rebreathing method: a new tool to determine total haemoglobin mass routinely," European Journal of Applied Physiology, vol. 95, no. 5-6, pp. 486-495, 2005.

[12] H. Dalen, A. Thorstensen, L. J. Vatten, S. A. Aase, and A. Stoylen, "Reference values and distribution of conventional echocardiographic Doppler measures and longitudinal tissue Doppler velocities in a population free from cardiovascular disease," Circulation: Cardiovascular Imaging, vol. 3, no. 5, pp. 614-622, 2010.

[13] S. C. Campbell, "A comparison of the maximum voluntary ventilation with the forced expiratory volume in one second: an assessment of subject cooperation," Journal of Occupational Medicine, vol. 24, no. 7, pp. 531-533, 1982.

[14] M. H. Whaley, ACSM's Guidelines for Exercise Testing and Perscription, Lippincott Williams \& Wilkins, Philadelphia, Pa, USA, 7th edition, 2006.

[15] P. Kokkinos and J. Myers, "Exercise and physical activity: clinical outcomes and applications," Circulation, vol. 122, no. 16, pp. 1637-1648, 2010.

[16] E. Edvardsen, B. H. Hansen, I. M. Holme, S. M. Dyrstad, and S. A. Anderssen, "Reference values for cardiorespiratory response and fitness on the treadmill in a 20 - to 85 -year-old population," Chest, vol. 144, no. 1, pp. 241-248, 2013.

[17] G. W. Heath, J. M. Hagberg, A. A. Ehsani, and J. O. Holloszy, "A physiological comparison of young and older endurance athletes," Journal of Applied Physiology Respiratory Environmental and Exercise Physiology, vol. 51, no. 3, pp. 634-640, 1981.

[18] T. M. Wilson and H. Tanaka, "Meta-analysis of the ageassociated decline in maximal aerobic capacity in men: relation to training status," The American Journal of Physiology-Heart and Circulatory Physiology, vol. 278, no. 3, pp. H829-H834, 2000.

[19] A. E. Pimentel, C. L. Gentile, H. Tanaka, D. R. Seals, and P. E. Gates, "Greater rate of decline in maximal aerobic capacity with age in endurance-trained than in sedentary men," Journal of Applied Physiology, vol. 94, no. 6, pp. 2406-2413, 2003.

[20] B. M. Nes, I. Janszky, U. Wisløff, A. Støylen, and T. Karlsen, "Age-predicted maximal heart rate in healthy subjects: the HUNT Fitness Study," Scandinavian Journal of Medicine and Science in Sports, vol. 23, no. 6, pp. 697-704, 2013.

[21] K. P. Davy and D. R. Seals, "Total blood volume in healthy young and older men," Journal of Applied Physiology, vol. 76, no. 5, pp. 2059-2062, 1994.

[22] W. Schmidt and N. Prommer, "Effects of various training modalities on blood volume," Scandinavian Journal of Medicine \& Science in Sports, vol. 18, supplement 1, pp. 57-69, 2008.

[23] K. Heinicke, B. Wolfarth, P. Winchenbach et al., "Blood volume and hemoglobin mass in elite athletes of different disciplines," International Journal of Sports Medicine, vol. 22, no. 7, pp. 504512, 2001.

[24] E.-A. Skaug, S. T. Aspenes, L. Oldervoll et al., "Age and gender differences of endothelial function in 4739 healthy adults: the HUNT3 fitness study," European Journal of Preventive Cardiology, vol. 20, no. 4, pp. 531-540, 2013.

[25] M. Guazzi, V. Adams, V. Conraads et al., "EACPR/AHA joint scientific statement. Clinical recommendations for cardiopulmonary exercise testing data assessment in specific patient populations," European Heart Journal, vol. 33, no. 23, pp. 29172927, 2012.

[26] C. E. Garber, B. Blissmer, M. R. Deschenes et al., "Quantity and quality of exercise for developing and maintaining cardiorespiratory, musculoskeletal, and neuromotor fitness in apparently healthy adults: guidance for prescribing exercise," Medicine and Science in Sports and Exercise, vol. 43, no. 7, pp. 1334-1359, 2011.

[27] B. H. Hansen, E. Kolle, S. M. Dyrstad, I. Holme, and S. A. Anderssen, "Accelerometer-determined physical activity in adults and older people," Medicine \& Science in Sports \& Exercise, vol. 44, no. 2, pp. 266-272, 2012. 


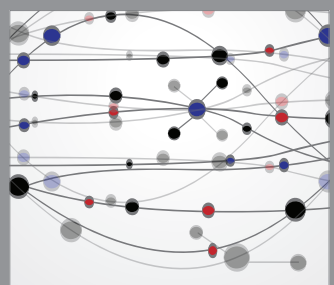

The Scientific World Journal
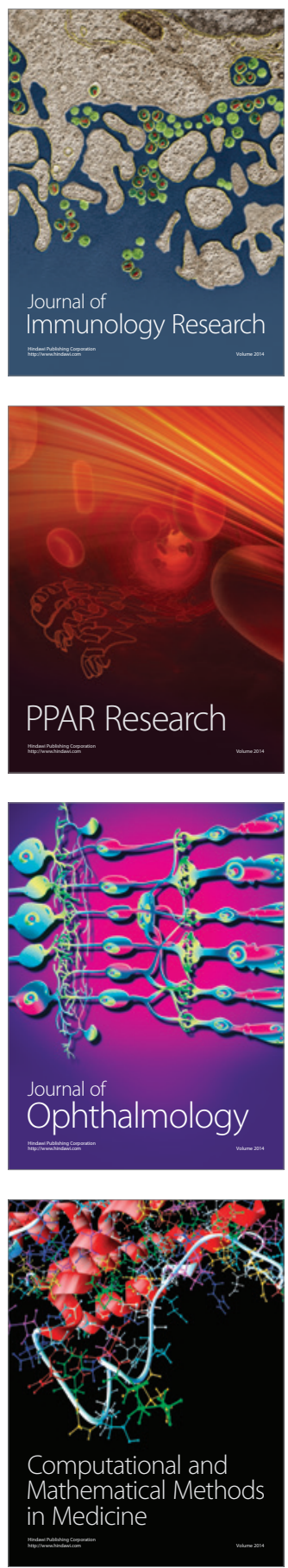

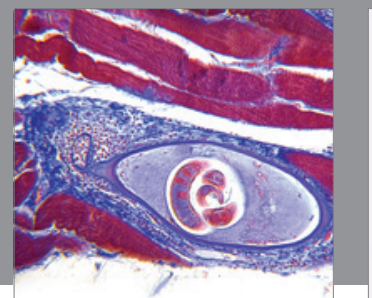

Gastroenterology

Research and Practice
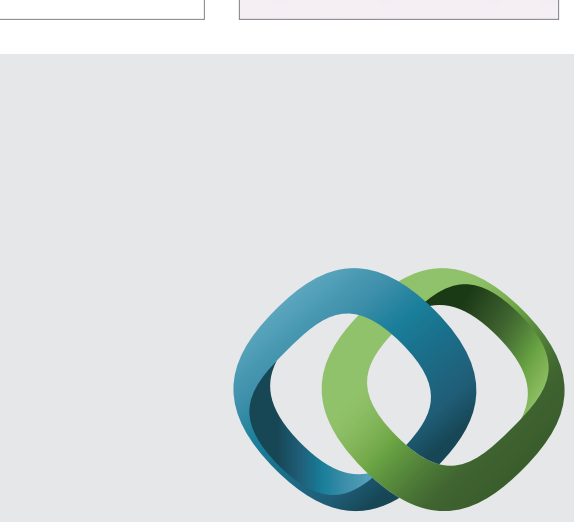

\section{Hindawi}

Submit your manuscripts at

http://www.hindawi.com
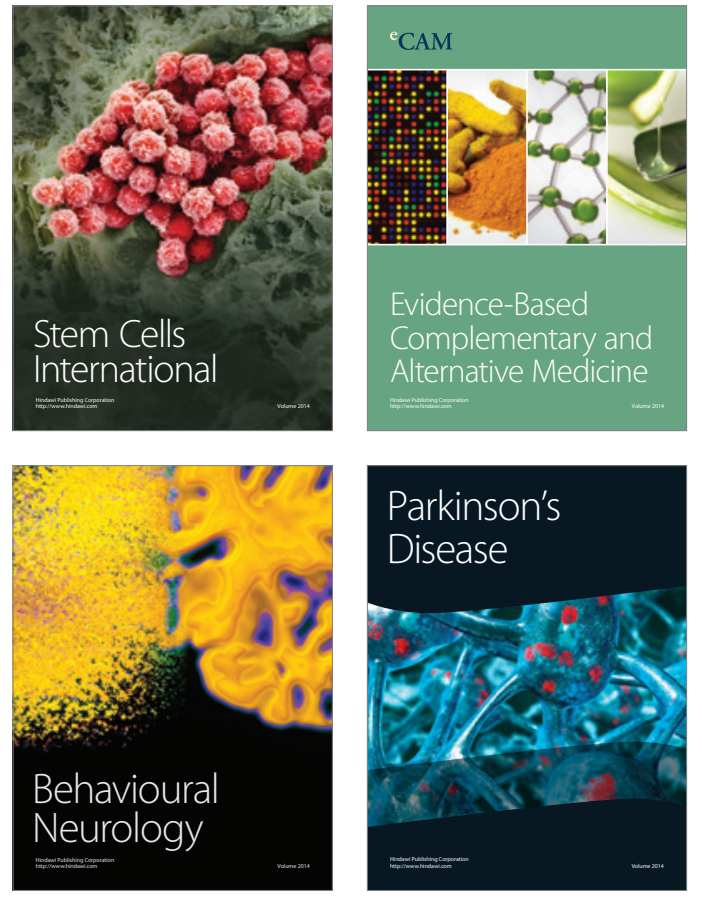
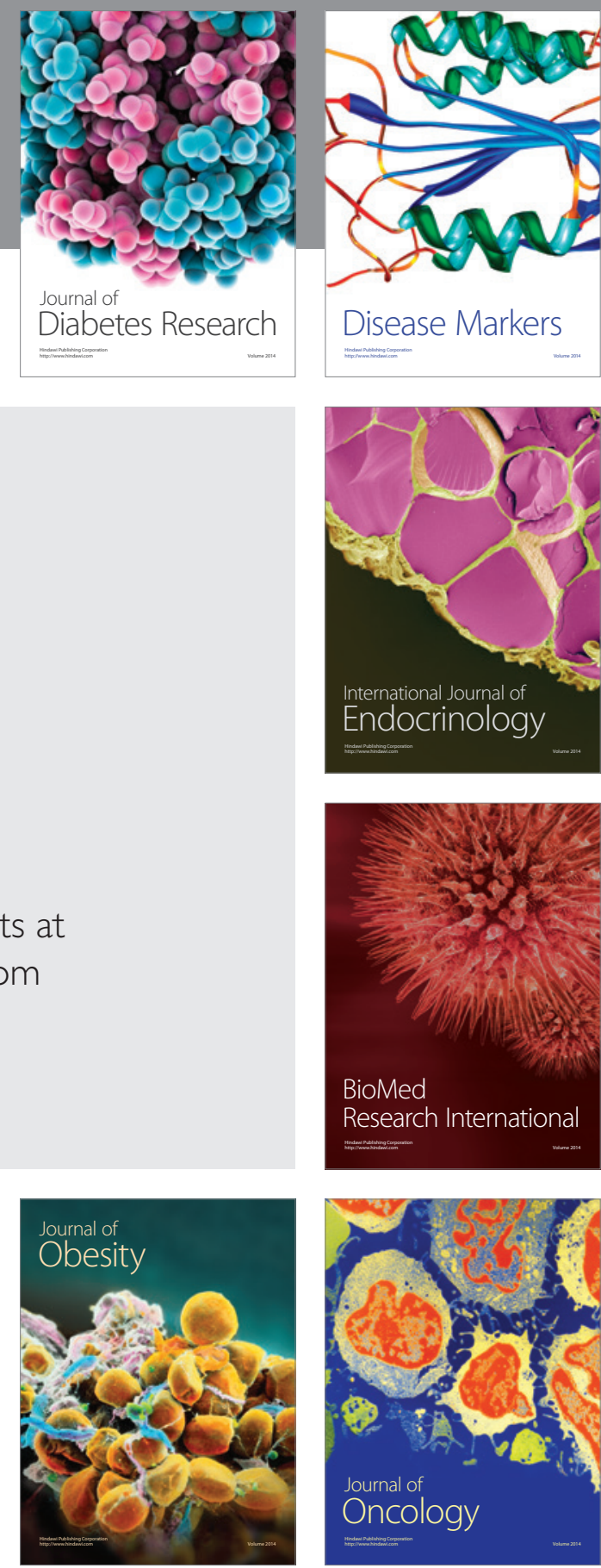

Disease Markers
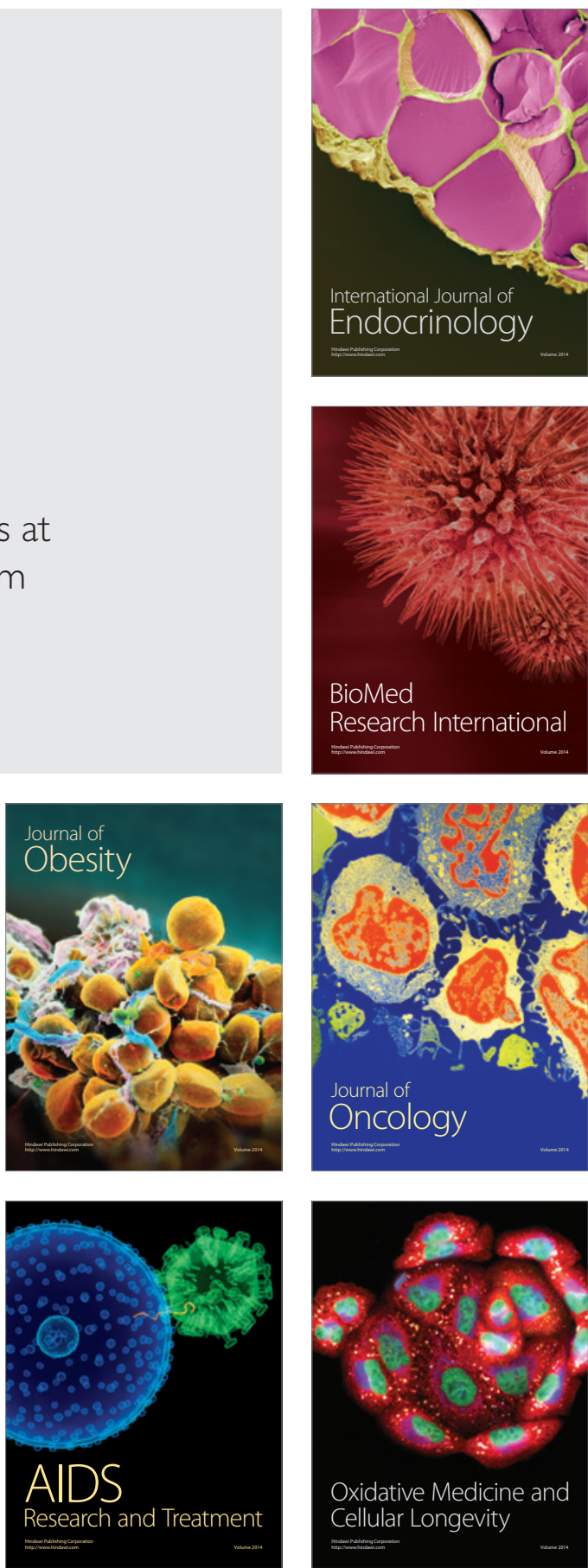